\title{
REKAYASA BAHAN MAKANAN DARI SINGKONG DALAM MENSEJAHTERAKAN PEREKONOMIAN MASYARAKAT DI KABUPATEN LABUHAN BATU UTARA
}

\author{
Pasca Dwi Putra $^{1 *}$, Lisyanto², Adek Cerah Kurnia Azis ${ }^{3}$, Andri Zainal ${ }^{4}$ \\ ${ }^{1}$ Program Studi Pendidikan Bisnis, Fakultas Ekonomi, Universitas Negeri Medan, Medan, Indonesia \\ ${ }^{2}$ Program Studi Pendikan Teknik Mesin, Fakultas Teknik, Universitas Negeri Medan, Medan, Indonesia \\ ${ }^{3}$ Program Studi Pendidikan Seni Rupa, Fakultas Bahasa dan Seni, Universitas Negeri Medan, Medan, Indonesia \\ ${ }^{4}$ Program Studi Pendidikan Akuntansi, Fakultas Ekonomi, Universitas Negeri Medan, Medan, Indonesia \\ *Penulis Korespondensi: sgacenter@gmail.com
}

\begin{abstract}
Abstrak
Singkong merupakan sumber karbohidrat bagi manusia setelah padi. Banyak masyarakat khususnya pedesaan yang memanfaatkan singkong sebagai sumber karbohidrat yang dikonsumsi setiap hari. Disamping itu, singkong banyak dijadikan olahan berupa keripik dan produk lainnya. Salah satunya di Kabupaten Labuhan Batu Utara Provinsi Sumatera Utara yang merupakan daerah dengan luas wilayah sebagian besar merupakan daerah pertanian dan perkebunan. Adapun produk olahan singkong yang dihasilkan didaerah ini berupa keripik singkong. Terdapat beberapa masalah yang dihadapi mitra berkaitan dengan produk olahan singkong ini seperti pemasaran yang hanya dilakukan didaerah sekitar, variasi produk yang terbatas berupa keripik singkong yang merupakan produk yang sudah banyak dikenal dan dikonsumsi oleh orang banyak serta kemasan dar produk yang masih sederhana dan kurang memiliki nilai jual. Adapun metode dalam menyelesaikan permasalahan ini berupa pendampingan terhadap mitra baik dari segi kewirausahaan, variasi produk, maupun desain kemasan produk. Hasil dari kegiatan ini berupa rekayasa bahan baku dan variasi produk lain selain keripik singkong sehingga menghasilkan produk yang inovasi dan kreatif dibandingkan dengan daerah lain. Selain itu, pemasaran tidak hanya dilakukan didaerah sekitar saja tetapi luar daerah melalui pemasaran lewat market place sehingga produk lebih dikenal secara luas. Kemasan yang lebih menarik membuat produk dari singkong ini lebih memiliki nilai ekonomi yang lebih besar.
\end{abstract}

Kata Kunci: Kewirausahaan; Market Place; Variasi Produk; Rekayasa Bahan Makanan.

\begin{abstract}
Cassava is a source of carbohydrates for humans after rice. Many communities, especially rural areas, use cassava as a source of carbohydrates consumed every day. Besides that, cassava is often made into processed in the form of chips and other products. One of them is in Labuhan Batu Utara Regency, North Sumatra Province which is an area with an area of mostly agricultural and plantation areas. The processed cassava products produced in this area are cassava chips. There are several problems faced by partners related to cassava processed products such as marketing which is only done in the surrounding area, limited product variation in the form of cassava chips which is a product that is widely known and consumed by many people and packaging of products that are still simple and have little value selling. The method of solving this problem is in the form of assistance to partners in terms of entrepreneurship, product variation, and product packaging design. The results of this activity are in the form of engineering raw materials and variations of other products besides cassava chips so as to produce innovative and creative products compared to other regions. In addition, marketing is not only done in the surrounding area but outside the region through marketing through market places so that the product is more widely known. More attractive packaging makes cassava products have more economic value.
\end{abstract}

Keywords: Entrepreneurship; Marketplace; Product Variation; Food Engineering. 


\section{PENDAHULUAN}

Persaingan global antar negara yang semakin ketat sekarang ini mengharuskan suatu negara memiliki keunggulan kompetitif. Sehingga negara berlombalomba dalam memanfaatkan sumber daya alamnya untuk menciptakan keunggulan yang tidak dimiliki oleh negara lain. Disamping itu, lambannya pertumbuhan ekonomi dari sektor riil mengharuskan banyak negara membuat inovasi dan kreativitas dengan mengembangkan kearifan lokal untuk meningkatkan pertumbuhan ekonomi dan kesejahteraan masyarakatnya secara umum (Paramita, Muhlisin, \& Palawa, 2018). Adapun isu yang cukup hangat dipertimbangkan adalah dengan mengembangkan usaha mikro kecil dan menengah (UMKM) dengan memanfaatkan potensi lokal yaitu kekayaan alam, budaya dan sumber daya disuatu daerah. Salah satunya adalah Indonesia. Negara Indonesia merupakan negara yang memiliki sumber daya alam yang cukup melimpah baik dari sisi pertanian, perkebunan, pertambangan, perikanan dan lainnya. Salah satunya pertanian dimana pada tahun 90-an, Indonesia telah mencapai swasembada pangan berupa padi. Disamping itu, keunggulan dalam bidang pertanian lainnya dimana Indonesia penghasil singkong atau ubi yang merupakan termasuk salah satu tanaman palawija yang merupakan tanaman kedua setelah padi (Muntoha, Jamroni, \& Riska, 2015; Ntelok, 2017; Septiriyani, 2017). Adapun yang termasuk kedalam tanaman palawija yaitu kacang tanah, kacang kedelai, jagung, kacang panjang, singkong, ubi jalar, dan lain sebagainya. Pada masa penjajahan Belanda dan Jepang dimana padi sangat sulit dan mahal untuk dibeli, banyak masyarakat Indonesia yang mengonsumsi ubi kayu ataupun singkong sebagai pengganti sumber karbohidrat dari beras (Pertanian, 2011; Saleh, Rahayuningsih, \& Widodo, 2008).

Tanaman singkong merupakan tanaman yang keseluruhannya dapat dimanfaatkan (Ntelok, 2017). Dimana daunnya dapat dimanfaatkan sebagai bahan pembuat sayur, batangnya dapat dimanfaatkan sebagai bahan bakar, dan akar atau umbinya dapat dimanfaatkan sebagai sumber karbohidrat. Perkembangan zaman sekarang ini dimana banyak muncul variasi makanan, sehingga singkong memiliki nilai yang rendah (Mumpuni \& Rasyid, 2008). Disamping itu, singkong termasuk tanaman lokal yang dikembangkan oleh masyarakat desa sehingga banyak masyarakat kota kurang mengenal ataupun memanfaatkan tanaman ini sebagai olahan makanan. Singkong dikatakan sumber karbohidrat dan sebagai pengganti nasi dikarenakan mengandung energi untuk 100 gr sebesar $154 \mathrm{kkal}$, protein 1 gr, karbohidrat 36,89, lemak 0,39, kalsium 77 $\mathrm{mg}$, fosfor $24 \mathrm{mg}$, dan zat besi 1,1 mg, vitamin B1 0,06 $\mathrm{mg}$ dan vitamin C $31 \mathrm{mg}$ (Pertanian, 2011; Saleh et al., 2008; Septiriyani, 2017).

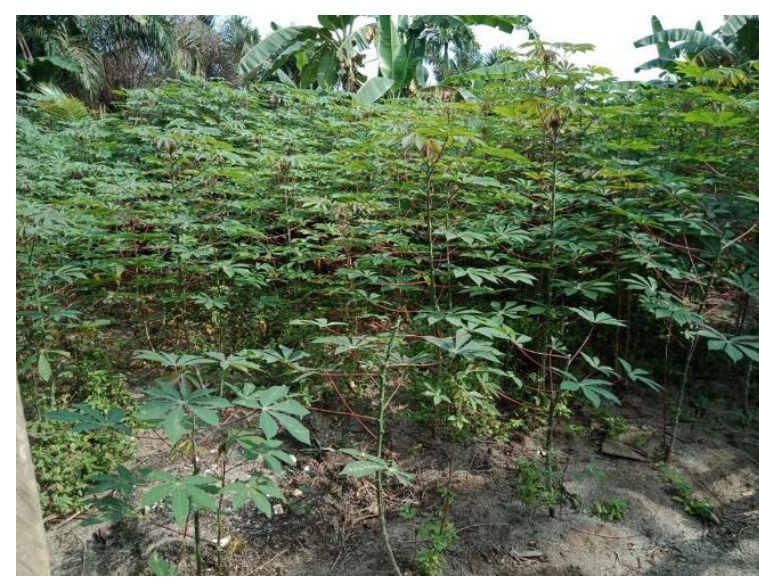

Gambar 1. Tanaman Singkong Mitra.

Salah satu daerah yang mempunyai potensi besar untuk singkong adalah Kabupaten Labuhan Batu Utara (Labura) Provinsi Sumatera Utara. Kabupaten yang memiliki luas sebesar $3.546,8 \mathrm{~km}^{2}$ ini memiliki luas wilayah yang sebagian besar pertanian dan perkebunan. Pada tahum 2016 jumlah panen singkong sebesar 93 ha dengan jumlah produksi 2.492 ton dan produktivitas 268 $\mathrm{kw} / \mathrm{ha}$.

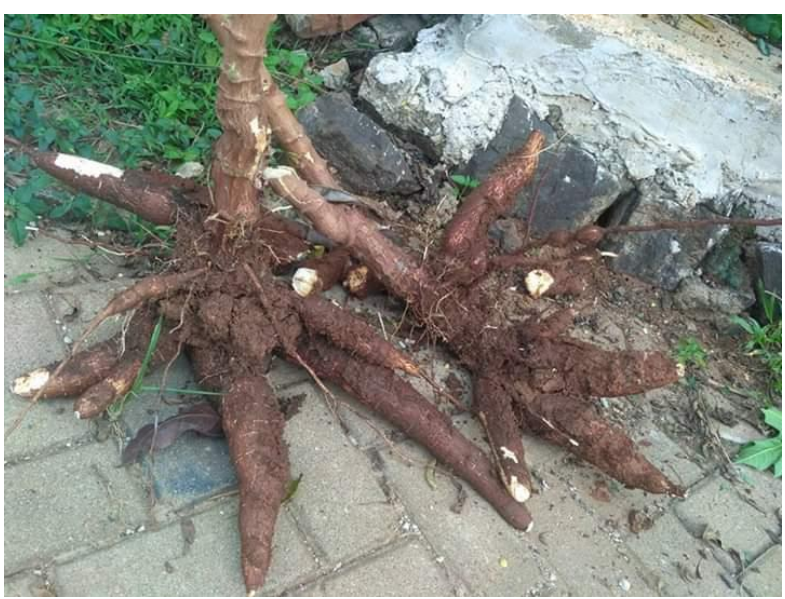

Gambar 2. Singkong Hasil Kebun Mitra.

Dari data tersebut menunjukkan bahwa daerah labura merupakan daerah yang memiliki potensi besar untuk mengembangkan tanaman singkong ini. Masyarakat labura selama ini mengolah bahan makanan dari singkong menjadi keripik yang merupakan makanan olahan dari singkong yang tidak asing lagi dikenal dan banyak diproduksi diberbagai daerah. Variasi produk dan rasanya juga sudah banyak dikenal sehingga diperlukan inovasi dan kreativitas untuk menjadikan suatu produk unggulan dari produk lainnya. Di Labura terdapat kelompok pengolah singkong dengan menghasilkan produk yang siap dikonsumsi dipasaran. Adapun produk yang biasa dihasilkan masyarakat berupa keripik ubi dan kue basah yang berbahan dasar singkong. Disamping itu, terdapat permasalahan yang dihadapi mitra seperti pemasaran yang dilakukan pada wilayah lokal saja serta kemasan yang masih sederhana. Selama ini, mitra hanya memasarkan produk diwilayah labura saja dikarenakan kurangnya pengetahuan berkaitan dengan pemasaran produk. Mitra hanya 
mengandalkan pemasaran dari toko ke toko atau dari mulut ke mulut sehingga arus kas yang diperoleh kecil dan membutuhkan waktu yang cukup lama. Salah satunya keripik singkong merupakan produk olahan dari singkong yang banyak diproduksi oleh daerah lain sehingga kalah saing dikarenakan tidak memiliki keunggulan dibandingkan dengan produk lain. Keripik singkong ini juga tidak memiliki kemasan yang menarik dan terkesan sederhana sehingga kurang diminati oleh masyarakat banyak. Jika kita lihat bahwa suatu kemasan produk harus menarik dan terdapat komposisi didalamnya. Sehingga diperlukan kemasan yang menarik dan unik untuk menarik perhatian konsumen. Berdasarkan permasalahan tersebut, maka perlu diberikan solusi dengan membantu pemasaran produk singkong sehingga menjadi produk unggulan serta memiliki kemasan yang menarik.

\section{METODE PELAKSANAAN}

Terdapat permasalahan berupa produk olahan singkong berupa keripik merupakan produk yang sudah banyak diproduksi secara luas sehingga dibutuhkan suatu inovasi dan kreativitas untuk menghasilkan produk lainnya seperti tepung mocaf (Cahyanto et al., 2018; Muntoha et al., 2015), tepung tapioca, gaplek, tape (Pertanian, 2011) dan produk lainnya. Permasalahan lainnya berupa wilayah pemasaran masih mencakup lokal sehingga kurang dikenal luas. Disamping itu, terdapat permasalahan berupa kemasan produk yang hanya dibungkus plastik dan nama produk sehingga kurang menarik. Oleh karena itu, diperlukan penyelesaian permasalahan diatas. Adapun metode pelaksanaan dari penyelesaian permasalahan tersebut berupa pendampingan dan pelatihan dalam melakukan pemasaran produk secara luas serta pendampingan dalam membuat kemasan produk menjadi lebih menarik. Adapun tahapan yang dilakukan dalam melakukan penyelesaian produk yaitu melakukan identifikasi terhadap permasalahan yang selama ini dialami oleh mitra, merancang kegiatan, sosialisasi atas solusi permasalahan, dan melakukan evaluasi dari kegiatan.

\section{HASIL DAN PEMBAHASAN}

\subsection{Hasil}

Berdasarkan permasalahan dari mitra, maka tim melakukan pendampingan terhadap penyelesaian permasalahan. Adapun pendampingan pertama yang dilakukan berupa memberikan pendampingan dan pelatihan berkaitan dengan kewirausahaan khususnya pemasaran. Mitra diberikan pelatihan dengan memberikan variasi media pemasaran yang dapat digunakan baik online maupun manual. Adapun pemasaran secara online dilakukan dengan memasarkan produk melalui market place sehingga produk dapat dikenal tidak hanya secara lokal tetapi juga nasional. Disamping itu, produk yang dihasilkan sudah banyak diproduksi oleh produk lain dan tidak memiliki keunggulan kompetitif lainnya sehingga dilakukan pendampingan untuk menghasilkan rekayasa produk bahan baku yang memiliki nilai ekonomi untuk menghasilkan produk berbahan dasar singkong. Salah satu inovasi bahan baku yang dihasilkan selain menghasilkan keripik singkong adalah tiwol. Tiwol yang dihasilkan dari ubi yang terlebih dahulu dijemur/dikeringkan kemudian digiling kasar.. Kemudian dari tepung tersebut dikukus dan ditambahkan dengan gula aren. Disamping itu, permasalahan lainnya berkaitan kemasan yang terlalu sederhana dan kurang memiliki nilai tambah untuk produk. Oleh karena itu, dilakukan pendampingan dalam mendesain kemasan sehingga menambah nilai ekonomi produk.

\subsection{Pembahasan}

Berdasarkan hasil dari pelaksanaan kegiatan diatas dapat dilihat berupa pendampingan pemasaran dengan memberikan pelatihan kewirausahaan. Hasil dari metode ini menunjukkan bahwa mitra tidak hanya memasarkan produk secara lokal atau sekitar labura saja tetapi sudah mulai secara luas khususnya daerah luar sekitar labura. Disamping itu, pemasaran secara juga tidak dilakukan secara manual tetapi juga secara online dengan memasarkan produk pemasaran di market place seperti tokopedia, elevania, shopee. Tujuannya melakukan pemasaran secara online yaitu memperkenalkan produk secara luas sehingga secara tidak langsung juga memperkenalkan keunggulan daerah.

Pendampingan menghasilkan produk lain selain keripik. Adapun metode yang dilakukan dengan memberikan pendampingan kepada mitra berkaitan dengan produk lain selain keripik sehingga produk tersebut menjadi produk yang inovasi dan kreatif serta berbeda dibandingkan dengan produk olahan dari daerah lain. Adapun produk olahan yang dihasilkan berupa rekayasa bahan baku dari singkong berupa singkong yang dikupas dan dikeringkan.

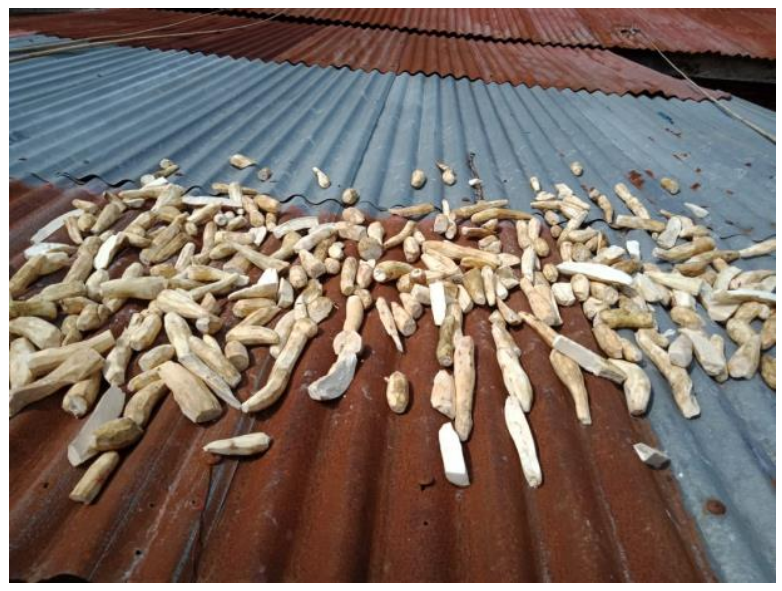

Gambar 3. Singkong Yang Dikeringkan.

Setelah kering, singkong tersebut dihaluskan dan siap digunakan. Salah satu produk yang dihasilkan dari tepung singkong ini adalah tiwol. Berikut hasil dari singkong yang telah dihaluskan. 


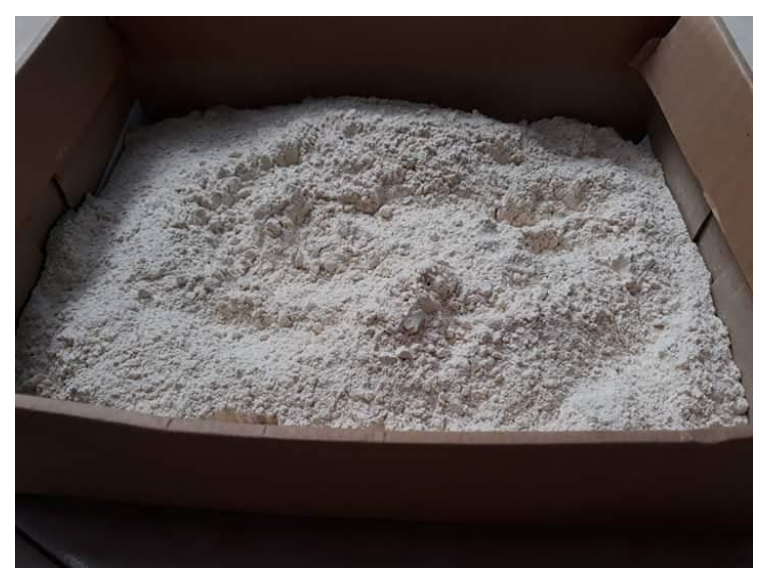

Gambar 4. Bahan Baku Membuat Tiwol.

Hasil dari produk ini menjadi lebih unggul dikarenakan menghasilkan rekayasa bahan baku yang lebih murah dan tidak kalah dengan produk yang sama dihasilkan oleh perusahaan industri besar. Disamping itu, rekayasa bahan baku ini dapat digunakan dalam waktu yang cukup lama dan bebas dari pengawet sehingga lebih sehat.

Pendampingan dalam membuat kemasaran produk menjadi lebih menarik. Adapun pendampingan dilakukan melalui mendesain kemasan produk menjadi lebih menarik dan memiliki nilai jual yang lebih tinggi. Kemasan berperan penting terhadap nilai jual ekonomis suatu produk sehingga kemasan yang menarik dan informative akan berdampak terhadap peningkatan penjualan produk.

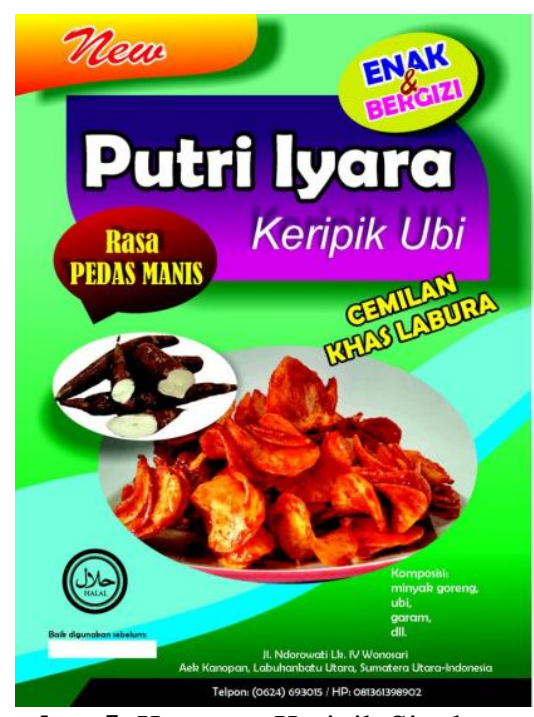

Gambar 5. Kemasan Keripik Singkong.

Oleh karena itu, dari hasil pendampingan kegiatan ini dihasilkan suatu kemasan produk yang menarik dan informatif sehingga kedepan akan memberikan nilai positif dan peningkatan penjualan terhadap produk. Adapun kemasan dari produk singkong ini memiliki warna dan gambar yang menarik sehingga konsumen tertarik untuk membeli produk tersebut.

\section{KESIMPULAN DAN SARAN}

Berdasarkan kegiatan diatas diperoleh kesimpulan bahwa rekayasan bahan baku melalui pengembangan produk yang lebih inovatif dan kreatif akan berdampak terhadap peningkatan nilai jual dan ekonomi dari produk singkong. Disamping itu, pemasaran yang dilakukan secara luas berdampak terhadap pengenalan produk tidak hanya dilakukan secara lokal tetapi regional maupun nasional sehingga berdampak terhadap pendapatan mitra. Disamping itu, pentingnya desain kemasan produk menjadi lebih menarik dan memiliki nilai jual akan memberikan pengaruh positif terhadap peningkatan penjualan produk. Adapun saran dalam kegiatan ini adalah kedepan mitra dapat memvariasikan produknya melalui integrasi pada berbagai produk olahan atau mitra sehingga adanya ketergantungan produk dari hasil rekayasa bahan baku untuk menghasilkan variasi produk olahan berbahan dasar singkong.

\section{REFERANSI}

Cahyanto, T., Supriyatna, A., Julita, U., Kusumorini, A., Hafsari, A. R., Suryani, Y., ... Salim, M. A. (2018). Pelatihan Inovasi Produk Pangan Berbahan Baku Singkong di Kecamatan Lembang Kabupaten Bandung Barat. Jurnal Bagimu Negeri, 2(1), 1-8. https://doi.org/10.26638/jbn.615.8651

Mumpuni, G., \& Rasyid, H. (2008). Kata Kunci: Ubi Kayu, Tiwul Instan, Peningkatan Pendapatan. Jurnal Dedikasi, 5, 1-13.

Muntoha, Jamroni, \& Riska, U. U. (2015). Pelatihan Pemanfaatan dan Pengolahan Singkong Menjadi Makanan Ringan Tela Rasa. Inovasi Dan Kewirausahaan, 4(3), 188-193.

Ntelok, Z. R. E. (2017). Limbah kulit singkong ( manihot esculenta 1.) : alternatif olahan makanan sehat. Jurnal Inovasi Pendidikan Dasar, l(1), 110-116.

Paramita, M., Muhlisin, S., \& Palawa, I. (2018). Peningkatan Ekonomi Masyarakat Melalui Pemanfaatan Sumber Daya Lokal. Qardhul Hasan: Media Pengabdian Kepada Masyarakat, 4(1), 19. https://doi.org/10.30997/qh.v4i1.1186

Pertanian, B. P. dan P. (2011). Agro inovasI 2 AgroinovasI. In Agroinovasi (Vol. edisi 4-10). Retrieved from www.litbang.deptan.go.id

Saleh, N., Rahayuningsih, S. A., \& Widodo, Y. (2008). Profil dan Peluang Pengembangan Ubi Jalar untuk Mendukung Ketahanan Pangan dan Agroindustri. Buletin Palawija, O(15), 21-30. https://doi.org/10.21082/bulpalawija.v0n15.200 8.p21-30

Septiriyani, V. I. (2017). Potensi Pemanfaatan Singkong (Manihot utilissima) Sebagai Bahan Tambahan Dalam Pembuatan Es Puter Secara Tradisional. Universitas Sanata Dharma. 